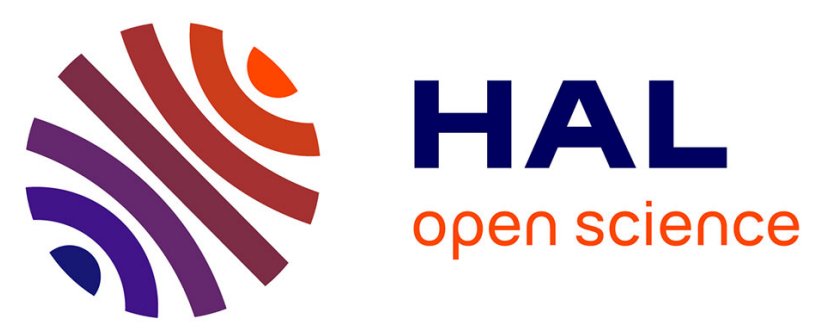

\title{
Trialkylamine-Catalyzed Aldolization of Unprotected 1,3-Dihydroxyacetone (DHA) toward C-C Bond-Linked Tetraol Surfactants
}

Biwen Zhu, Dorine Belmessieri, Jesús Fermin Ontiveros, Jean-Marie Aubry, Guo-Rong Chen, Nicolas Duguet, Marc Lemaire

\section{To cite this version:}

Biwen Zhu, Dorine Belmessieri, Jesús Fermin Ontiveros, Jean-Marie Aubry, Guo-Rong Chen, et al.. Trialkylamine-Catalyzed Aldolization of Unprotected 1,3-Dihydroxyacetone (DHA) toward C-C BondLinked Tetraol Surfactants. ACS Sustainable Chemistry \& Engineering, 2018, 6 (2), pp.2630-2640. 10.1021/acssuschemeng.7b04135 . hal-02128577

\section{HAL Id: hal-02128577 https://hal-udl.archives-ouvertes.fr/hal-02128577}

Submitted on 1 Jun 2021

HAL is a multi-disciplinary open access archive for the deposit and dissemination of scientific research documents, whether they are published or not. The documents may come from teaching and research institutions in France or abroad, or from public or private research centers.
L'archive ouverte pluridisciplinaire HAL, est destinée au dépôt et à la diffusion de documents scientifiques de niveau recherche, publiés ou non, émanant des établissements d'enseignement et de recherche français ou étrangers, des laboratoires publics ou privés. 


\section{Trialkylamine-Catalyzed Aldolisation of}

\section{Unprotected 1,3-Dihydroxyacetone (DHA) towards}

\section{C-C Bond-Linked Tetraol Surfactants}

Biwen Zhu, ${ }^{a}$ Dorine Belmessieri, ${ }^{a}$ Jesús Fermin Ontiveros, ${ }^{b}$ Jean-Marie Aubry, ${ }^{b}$ Guo-Rong Chen, ${ }^{c}$ Nicolas Duguet, ${ }^{* a}$ Marc Lemaire ${ }^{*, a}$

${ }^{a}$ Univ Lyon, Université Claude Bernard Lyonl, CNRS, INSA-Lyon, CPE-Lyon, Institut de Chimie et Biochimie Moléculaires et Supramoléculaires, ICBMS, UMR 5246, Equipe CAtalyse, SYnthèse et ENvironnement (CASYEN), 43, bd du 11 novembre 1918, F-69622 Villeurbanne cedex, France.

${ }^{b}$ Univ. Lille, CNRS, ENSCL, UMR 8181, UCCS, Unité de Catalyse et Chimie du Solide, F-59000 Lille, Cité Scientifique, France.

${ }^{c}$ Key Laboratory for Advanced Materials \& Institute of Fine Chemicals, School of Chemistry and Molecular Engineering, East China University of Science and Technology, 130 Meilong Road, Shanghai 200237, P. R. China

e-mails: nicolas.duguet@univ-lyon1.fr, $\underline{\text { marc.lemaire.chimie@univ-lyon1.fr }}$

ABSTRACT. The aldolisation of unprotected 1,3-dihydroxyacetone (DHA) was studied under mild conditions $\left(20^{\circ} \mathrm{C}\right)$ in a mixture of water/EtOH using hydrocinnamaldehyde as a model 
substrate. It was shown that trimethylamine is the most effective base for this transformation giving the corresponding aldol with up to $98 \%$ selectivity and $82 \%$ yield. The method was extended to a range of (bio-based) aldehydes to give $\alpha$-hydroxyketones with $29-70 \%$ isolated yields. These $\alpha$-hydroxyketones were reduced under hydrogen using $5 \%-\mathrm{Ru} / \mathrm{Al}_{2} \mathrm{O}_{3}$ in $\mathrm{EtOH}$ at $100^{\circ} \mathrm{C}$ to give tetraols with $79-97 \%$ isolated yields. The physico-chemical properties of these tetraols were studied (CMC, Krafft point, PIT-slope method) and these studies revealed that this new class of $\mathrm{C}-\mathrm{C}$ bond linked non-ionic surfactants exhibit high effectiveness reducing the surface tension of water.

KEYWORDS. Aldolisation, 1,3-Dihydroxyacetone, Surfactants, Tetraols, Trialkylamines

\section{INTRODUCTION}

Surfactants are widely used in detergency, cosmetics, pharmaceuticals and as additives in paints, textiles and food. Among all surfactants developed so far, renewable surfactants are now occupying an increasingly important place. ${ }^{1,2}$ In this context, carbohydrate-derived surfactants have attracted a lot of attention as they are inherently obtained from renewable resources (starch, hemicellulose, cellulose, saccharose). ${ }^{3}$ Moreover, carbohydrates are available in bulk quantities at a very competitive price, that is particularly interesting for surfactants targeting industrial applications. ${ }^{4}$ In addition, carbohydrates are generally non-toxic and biodegradable. For example, alkyl (poly)glycosides (APGs) are commercially available non-ionic surfactants that are widely used in detergency thanks to their good biodegradability. ${ }^{5,6}$ Most of the other carbohydrate-based surfactants have an ester linkage between the polar head and the hydrophobic tail such as sucrose esters, ${ }^{7}$ and sorbitan esters ${ }^{8}$ amongst others. The ester functional 
group is usually privileged for three reasons, that are: i) the wide availability and great diversity of polyols and carboxylic acids, ii) the relative simplicity of formation (through chemical or enzymatic catalysis) and iii) the good biodegradability properties. However, the ester group is sensitive to hydrolysis in acid or basic conditions, thus restricting their applications over a narrow range of $\mathrm{pH}$. Still, there is a need of robust surfactants, particularly for extraction purposes (e.g., eco-extraction of natural products), and for applications requiring medium-tolong-term stability upon storage (e.g., cosmetics).

In order to increase the stability of surfactants, many efforts have been devoted to the preparation of ether analogues such as glycerol ethers. ${ }^{9}$ However, they are only few examples of the preparation of carbohydrate-derived ethers. In this field, our group has recently reported the access to sorbitan ${ }^{10,11}$ and methyl glycopyranoside ${ }^{12,13}$ alkyl ethers through the reductive alkylation (reductive etherification) of the corresponding polyols. Another option to increase the stability is to link the polar head and the non-polar part with a robust C-C bond. Albeit very attractive from a synthetic point of view, this approach has been scarcely explored. To the best of our knowledge, there is only one report on carbohydrate derivatives. In 2011, Foley et al. have reported the access to linear and cyclic C-glycosides surfactants from Lubineau's nonulose ${ }^{14}$ through enamine-catalysed aldol condensation using a range of alkyl aldehydes. ${ }^{15}$

Among the available renewable starting materials, 1,3-dihydroxyacetone (DHA) is a versatile C3-building-block for asymmetric synthesis ${ }^{16}$ but it has barely been explored as starting material for surfactant applications. DHA is naturally present in sugar beets but only in small quantities, which are not sufficient for the targeted applications. However, DHA can be produced by direct oxidation of glycerol through organometallic ${ }^{17}$ or enzymatic ${ }^{18}$ catalysis. Glycerol is a renewable platform molecule (obtained from the hydrolysis or methanolysis of triglycerides) that is 
available in bulk quantities and at a low price. ${ }^{19,20}$ Therefore, glycerol-derived DHA presents similar assets, making it suitable for surfactants applications. The aldolisation of DHA has been previously investigated using aldolases as biocatalysts. However, most biocatalytic methods have been reported using dihydroxyacetone phosphate (DHAP) as starting material due to its ability to interact with enzyme active sites (Scheme 1, a). ${ }^{21,22}$

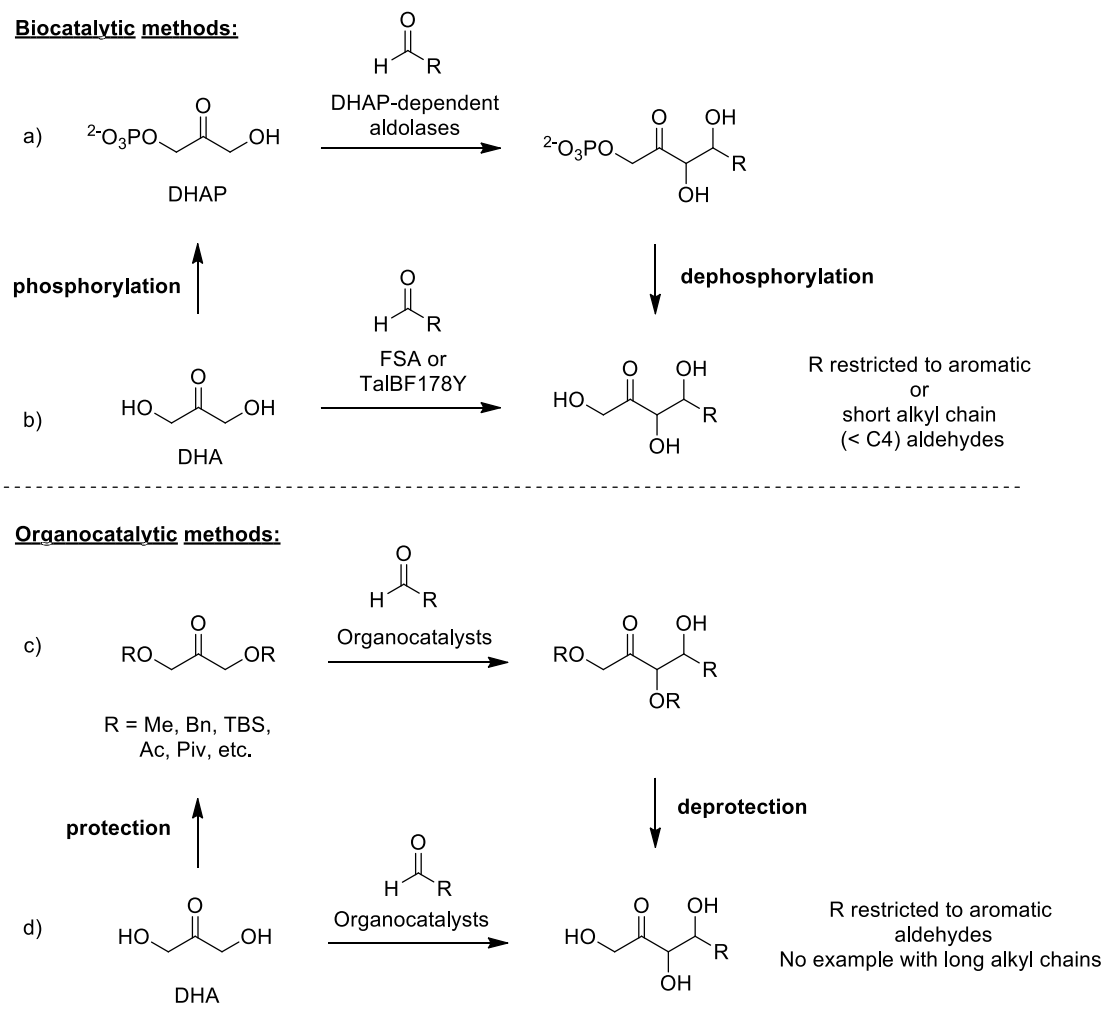

Scheme 1. Bio- and organocatalytic methods for the aldolisation of (protected) DHA.

This requires two extra steps for preliminary phosphorylation of DHA and deprotection of the phosphate group at end-stage. Only a few enzymes such as D-fructose-6-phosphate aldolase $(\mathrm{FSA})^{23}$ from Escherichia coli or TalB ${ }^{\mathrm{F} 178 \mathrm{Y}}$, a F178Y mutant of transaldolase B ${ }^{24}$ could accept unprotected DHA as substrate (Scheme 1, b). Unfortunately, the aldehyde substrate scope is 
limited to aromatic aldehydes or short alkyl chain aldehydes $(\leq \mathrm{C} 4)$ with electron withdrawing substituent. ${ }^{25}$ Many organocatalytic methods have been developed for the aldolisation of DHA towards the formation of stereogenic centres. As a result, most of these methods use protected versions of DHA or cyclic analogues, mainly for selectivity reasons (Scheme 1, c). ${ }^{26-28}$ In some cases, unprotected DHA could be used but the substrate scope is generally limited to aromatic aldehydes (Scheme 1, d) ${ }^{29,30}$ In this context, there is a need to develop clean methodologies for the aldolisation of unprotected DHA using linear enolizable aldehydes under mild conditions.

Herein, we report the use of trialkylamines for the aldolisation of unprotected 1,3dihydroxyacetone with a range of (bio-based) aromatic and linear aldehydes. The resulting $\alpha$ hydroxyketones were reduced to the corresponding tetraols and their physico-chemical properties were studied in details (Scheme 2).

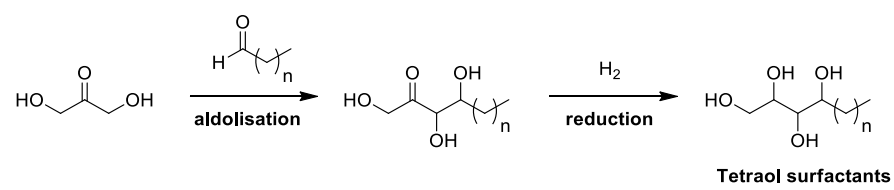

Scheme 2. Tetraol surfactants through an aldolisation/reduction sequence.

\section{RESULTS AND DISCUSSION}

\section{Synthesis of tetraols through aldolisation/reduction}

Initial screening was carried out to find appropriate conditions for the aldolisation of unprotected DHA using hydrocinnamaldehyde (HCA) as a model substrate (Table 1).

Table 1. Optimization of reaction conditions. ${ }^{a}$ 


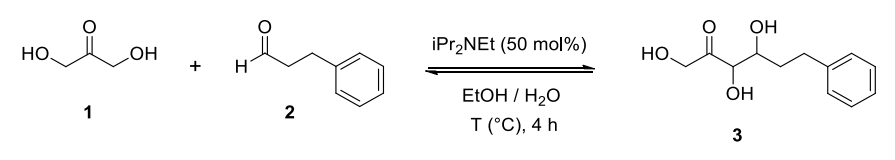

\begin{tabular}{lllllll}
\hline Entry & $\mathbf{1} / \mathbf{2}$ ratio & $\begin{array}{l}\mathrm{EtOH} / \mathrm{H}_{2} \mathrm{O} \\
\text { ratio }\end{array}$ & $\begin{array}{l}\mathrm{T} \\
\left({ }^{\circ} \mathrm{C}\right)\end{array}$ & $\begin{array}{l}\text { Conv. } \\
(\%)\end{array}$ & $\begin{array}{l}\text { Yield }^{c} \\
(\%)\end{array}$ & $\begin{array}{l}\text { Selec. }^{d} \\
(\%)\end{array}$ \\
\hline 1 & $5: 1$ & $1: 1$ & 20 & $>99$ & 46 & 46 \\
2 & $10: 1$ & $1: 1$ & 20 & $>99$ & 72 & 72 \\
3 & $15: 1$ & $1: 1$ & 20 & $>99$ & 89 & 89 \\
4 & $20: 1$ & $1: 1$ & 20 & $>99$ & $>99$ & 99 \\
$5^{e}$ & $5: 1$ & $1: 1$ & 20 & 73 & 65 & 89 \\
$6^{e}$ & $5: 1$ & $10: 1$ & 20 & $>99$ & $<1$ & 1 \\
$7^{e}$ & $5: 1$ & $1: 10$ & 20 & 98 & 11 & 11 \\
$8^{e}$ & $5: 1$ & $1: 1$ & 30 & 84 & 12 & 14 \\
$9^{e}$ & $5: 1$ & $1: 1$ & 50 & 74 & 8 & 11 \\
$10^{f}$ & $5: 1$ & $1: 1$ & 20 & 83 & 64 & 77
\end{tabular}

${ }^{a}$ Reaction conditions: sealed tube, dihydroxyacetone 1 (500 mg, $\left.5.5 \mathrm{mmol}\right)$, DHA (5-20 equiv.), ${ }_{i P r} \mathrm{PEt}_{2}(50 \mathrm{~mol} \%), \mathrm{H}_{2} \mathrm{O} / \mathrm{EtOH}(5 \mathrm{~mL}), \mathrm{T}\left(20-50^{\circ} \mathrm{C}\right), 4$ hours. ${ }^{b}$ The conversion is based on the aldehyde. ${ }^{c}$ Results were determined by HPLC using calibration curves. ${ }^{d}$ Selectivity was calculated as follow: $\mathrm{S}=$ yield / conversion. ${ }^{e}$ Dropwise addition of aldehyde $\mathbf{2}$ into a solution of DHA. ${ }^{f}$ Reaction carried out with only $10 \mathrm{~mol} \%$ of catalyst for 4 days.

First, the aldolisation of DHA 1 (5 equiv.) with hydrocinnamaldehyde 2 (1 equiv.) was carried out in a 1:1 mixture of $\mathrm{EtOH} / \mathrm{H}_{2} \mathrm{O}$ at room temperature $\left(20^{\circ} \mathrm{C}\right)$ using $\mathrm{iPr}_{2} \mathrm{NEt}(50 \mathrm{~mol} \%)$. Satisfyingly, the conversion is complete after 4 hours and $\alpha$-hydroxyketone $\mathbf{3}$ was obtained with $46 \%$ yield (Table 1, entry 1). However, a significant proportion (about 20\%) of a heavier byproduct was formed under these conditions. This byproduct comes from the bis-aldolisation of 
DHA with two equivalents of aldehyde $\mathbf{2}$ as confirmed by HRMS (see ESI). In order to prevent its formation, the amount of DHA was progressively increased from 5 to 20 equivalents (Table 1, entries 2-4). Gratifyingly, the yield of $\alpha$-hydroxyketone 3 increased from 72 to $99 \%$ when using 20 equivalents and no di-aldol product has been detected under these conditions. Considering that the aldolisation is a reversible process, these results clearly indicate that a high DHA/HCA ratio should be employed to reach high yield and selectivity. However, in order to limit the quantity of DHA, the DHA/HCA ratio was set at 5 like in most reported literature procedures. ${ }^{31}$ Consequently, the reaction was carried out by dropwise addition of aldehyde 2 to a DHA solution to maintain high concentration of DHA (Table 1, entry 5). Under these conditions, the yield of 3 reached $65 \%$ and the selectivity was $89 \%$. Moreover, only traces $(<5 \%)$ of the bisaldolisation product of DHA has been observed, thus confirming the high selectivity obtained. The proportions of EtOH and water were next investigated using a 10-fold of one of the solvent. With a 10:1 EtOH/water ratio, the conversion is high but the yield is poor (Table 1, entry 6). Only the self-aldolisation product of hydrocinnamaldehyde has been observed under these conditions. With a 1:10 EtOH/water ratio, once again the conversion is high but the yield is low (Table 1, entry 7). In that case, a large amount of the bis-aldolisation product was obtained. Finally, increasing the temperature to 30 or $50{ }^{\circ} \mathrm{C}$ did not improve the yield of the desired $\alpha$ hydroxyketone 3 (Table 1, entries 8-9). It should be noted that similar results could be obtained using only $10 \mathrm{~mol} \%$ of $\mathrm{iPr}_{2} \mathrm{NEt}$ provided extended reaction times (4 days) (Table 1, entry 10). This is not surprising as most literature procedures using organocatalysts $(10-30 \mathrm{~mol} \%)$ require 1 to 7 days. ${ }^{26-30}$ Consequently, the amine loading was set at $50 \mathrm{~mol} \%$ in order to keep short reaction times for rapid optimization. 
Several traditional aldolisation catalysts such as $\mathrm{Zn}(\operatorname{Pro})_{2},{ }^{32} L$-proline, ${ }^{33}$ cinchonidine, quinine and others were next screened under the optimized reaction conditions but they gave poor results (see Table S1 in ESI for details). Only trialkylamines with non-bulky substituents gave interesting results (Table 2).

Table 2. Catalyst screening. ${ }^{a}$

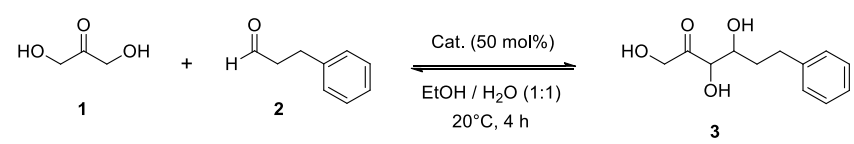

\begin{tabular}{|c|c|c|c|c|}
\hline Entry & Catalyst & $\begin{array}{l}\text { Conv. }{ }^{b, c} \\
(\%)\end{array}$ & $\begin{array}{l}\text { Yield }^{c} \\
(\%)\end{array}$ & $\begin{array}{l}\text { Selec }^{d} \\
(\%)\end{array}$ \\
\hline 1 & $i$ - $\operatorname{Pr}_{2} \mathrm{NEt}$ & 94 & 54 & 57 \\
\hline 2 & $\mathrm{Et}_{3} \mathrm{~N}$ & 53 & 51 & 96 \\
\hline 3 & $\mathrm{EtNMe}_{2}$ & 78 & 73 & 93 \\
\hline $4^{e}$ & $\mathrm{NMe}_{3}$ & 84 & 82 & 98 \\
\hline 5 & $n-\mathrm{C}_{12} \mathrm{H}_{25} \mathrm{NMe}_{2}$ & 33 & 26 & 79 \\
\hline \multicolumn{5}{|c|}{${ }^{a}$ Reaction conditions: sealed tube, 1,3-dihydroxyacetone 1 ( $500 \mathrm{mg}, 5.5 \mathrm{mmol}, 5$ equiv), } \\
\hline \multicolumn{5}{|c|}{ hydrocinnamaldehyde 2 (148 mg, $1.1 \mathrm{mmol})$, catalyst (50 mol\%), $\mathrm{H}_{2} \mathrm{O} / \mathrm{EtOH}(1: 1,5 \mathrm{~mL}), 20^{\circ} \mathrm{C}$, } \\
\hline \multicolumn{5}{|c|}{4 hours. ${ }^{b}$ The conversion is based on the aldehyde. ${ }^{c}$ Results were determined by HPLC using } \\
\hline \multicolumn{5}{|c|}{ calibration curves. ${ }^{d}$ Selectivity was calculated as follow: $\mathrm{S}=$ yield $/$ conversion. ${ }^{e}$ Reaction was } \\
\hline
\end{tabular}

Hünig's base ( $\left.{ }^{i} \mathrm{Pr}_{2} \mathrm{NEt}\right)$ gave a high conversion but a moderate selectivity (Table 2, entry 1). Other trialkylamines were found particularly selective (93-98\%) for the formation of $\alpha$ hydroxyketone 3 (Table 2, entry 2-4). From these results, a trend can be identified: the smaller the substituents on trialkylamine, the better the yield. Indeed, the yield of 3 reached $82 \%$ when 
using $\mathrm{NMe}_{3}$ as catalyst (Table 2, entry 4). Finally, the catalytic activity of dodecyldimethylamine was tested as we envisaged that it could have a surfactant-like behaviour that could enhance the solubility of aldehyde $\mathbf{2}$ in water/EtOH solvent mixture. Unfortunately, only moderate results were obtained, thus refuting this hypothesis (Table 2, entry 5).

Consequently, the substrate scope was next extended to a range of (bio-based) aldehydes using $\mathrm{NMe}_{3}$ as catalyst (Table 3). Repeating the reaction with hydrocinnamaldehyde 2 gave the corresponding $\alpha$-hydroxyketone $\mathbf{3}$ with $65 \%$ isolated yield after purification by column chromatography (Table 3, entry 1). The product was obtained as a 95:5 mixture of diastereoisomers as determined by ${ }^{1} \mathrm{H}$ NMR (the 2 diastereoiomers could not be assigned unambiguously). A series of linear aldehydes, with increasing alkyl chain length from 4 to 12 carbons, were next considered. They could be obtained by reduction of the corresponding fatty acids which are accessible from vegetable oil derivatives. The corresponding $\alpha$-hydroxyketone 4-8 were isolated with moderate yields (46-53\%) (Table 3, entries 2-5). The use of dodecanal gave even a lower yield of $\alpha$-hydroxyketone $\mathbf{8}$ due to the poor solubility of dodecanal in the reaction mixture (Table 3, entry 6). The use of citronellal as pine wood-derived aldehyde could also be used and the aldol product 9 was isolated with $42 \%$ yield (Table 3, entry 7). Conversely, bifunctional aldehyde, derived from the cleavage of fatty acid derivatives, ${ }^{34-36}$ gave $\mathbf{1 0}$ with moderate yield but a high 95:5 d.r. (Table 3 , entry 8). Finally, carbohydrate-derived ${ }^{37}$ furfural gave 11 with a satisfying $70 \%$ yield (Table 3 , entry 9). 
Table 3. Scope for the aldolisation of DHA with a range of aldehydes. ${ }^{a}$

$$
\mathrm{R}_{\mathrm{H}}+\mathrm{H}_{\mathrm{H}} \underset{\substack{\mathrm{O} \\ \mathrm{EtOH} / \mathrm{H}_{2} \mathrm{O}(1: 1) \\ 20^{\circ} \mathrm{C}, 3 \mathrm{~h}}}{\frac{(50 \mathrm{~mol} \%)}{\mathrm{NMe}_{3}}}
$$

\begin{tabular}{|c|c|c|c|c|}
\hline Entry & $\alpha$-hydroxyketones & & Yield $^{b}(\%)$ & d.r. ${ }^{c}$ \\
\hline 1 & & 3 & $65(57)^{d}$ & $95: 5$ \\
\hline 2 & & 4 & $46(41)^{d}$ & $96: 4$ \\
\hline 3 & & 5 & $49(42)^{d}$ & $96: 4$ \\
\hline 4 & & 6 & $48(40)^{d}$ & $91: 9$ \\
\hline 5 & & 7 & $53(48)^{d}$ & $90: 10$ \\
\hline $6^{e}$ & & 8 & 29 & $92: 8$ \\
\hline 7 & & 9 & 42 & $53: 47$ \\
\hline 8 & & 10 & 36 & $95: 5$ \\
\hline 9 & & 11 & 70 & $68: 32$ \\
\hline
\end{tabular}

${ }^{a}$ Reaction conditions: sealed tube, aldehyde (2.2 mmol), DHA ( $1 \mathrm{~g}, 11 \mathrm{mmol}, 5$ equiv), Et $3 \mathrm{~N}$ (50 mol\%), $\mathrm{H}_{2} \mathrm{O} / \mathrm{EtOH}(1: 1,10 \mathrm{~mL}), 20^{\circ} \mathrm{C} .{ }^{b}$ Isolated yields after purification by column chromatography. ${ }^{c}$ Diastereomeric ratios were determined by ${ }^{1} \mathrm{H}$ NMR. ${ }^{d}$ Isolated yields in brakets were obtained using $\mathrm{NEt}_{3}(50 \mathrm{~mol} \%)$ for 7 hours. ${ }^{e}$ Reaction was carried out at $32^{\circ} \mathrm{C}$.

Contrary to most biocatalytic and organocatatylic methods reported so far, which require prolonged reaction times (up to several days), this method requires only short reaction times (3 hours) provided a high catalyst loading. Consequently, it is essential to recover the catalyst to 
make this method attractive from economical and environmental points of view. We have first attempted to use heterogeneous catalysts to provide a recyclable system but the results were not satisfying (see Table S2 in ESI for details). Consequently, considering that the catalyst used $\left(\mathrm{NMe}_{3}\right)$ has a low boiling point $\left(\mathrm{bp}=3-4^{\circ} \mathrm{C}\right)$, we decided to take advantage of this volatility to recover it. Hence, after reaction of DHA with aldehyde 2, trimethylamine was evaporated at room temperature under vacuum (80 mbar) and the vapours were condensed into two consecutive dry ice/acetone traps. This distillation should be carried out at room temperature in order to avoid the degradation of the $\alpha$-hydroxyketone $\mathbf{3}$ to the starting materials through a retroaldolisation process. The collected catalyst was titrated with a $1 \mathrm{M}$ aqueous $\mathrm{HCl}$ solution. Unfortunately, the maximum yield of the recovered $\mathrm{NMe}_{3}$ did not exceed $16 \%$ due to its extremely high volatility that makes the recycling difficult on a small scale using standard laboratory equipment. As a result, in order to validate this concept, trimethylamine was substituted by less volatile triethylamine $\left(b p=89^{\circ} \mathrm{C}\right.$ ) as it gave similar results than $\mathrm{NMe}_{3}$ (see Table 3, entries 1-5, yields in brakets). In this case, the catalyst was recovered with $77 \%$ yield as a solution in $\mathrm{EtOH} /$ water without erosion of the reaction yield of the $\alpha$-hydroxyketone 3 (Figure 1).

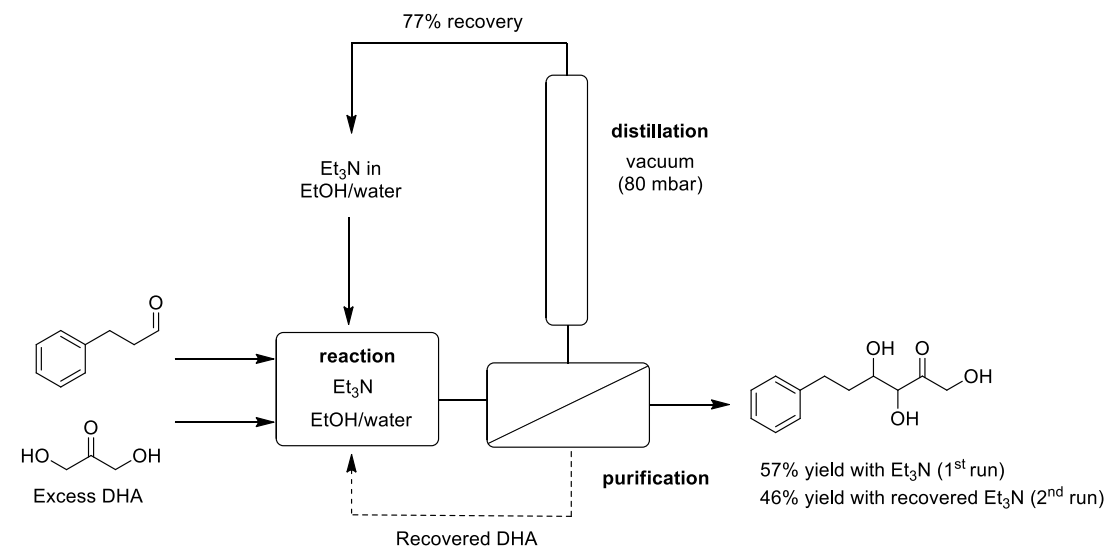


Figure 1. Process for the aldolisation of DHA including recycling of trialkylamine catalysts and recovery of excess DHA.

This EtOH/water solution containing the catalyst was directly re-used in another batch for the aldolisation of DHA with aldehyde 2 and the corresponding $\alpha$-hydroxyketone $\mathbf{3}$ was recovered with $46 \%$ isolated yield. Overall, these results, with other recent works on the isomerization of glucose to fructose $\mathrm{e}^{38}$ and the hydrothermal liquefaction of algae residues, ${ }^{39}$ highlight the potential of trialkylamines as recoverable organocatalysts for the valorization of biomass.

The hydrogenation of $\alpha$-hydroxyketones to the corresponding tetraols was next investigated (Table 4). The hydrogenation of $\alpha$-hydroxyketone 3 was first carried out under 40 bars of hydrogen using $5 \%-\mathrm{Ru} / \mathrm{Al}_{2} \mathrm{O}_{3}(5 \mathrm{~mol} \%)$ in $\mathrm{EtOH}$ at $100^{\circ} \mathrm{C}$. These conditions led to the reduction of the keto group but with concomitant reduction of the phenyl ring, giving tetraol 12 with $95 \%$ isolated yield (Table 4, entry 1). Almost no selectivity was detected as the product was obtained as a 56:44 mixture of diastereoisomers. In order to avoid the reduction of the phenyl ring, the hydrogen pressure was decreased to 5 bars and the temperature to $30^{\circ} \mathrm{C}$ to give the desired tetraol 13 with 94\% isolated yield (Table 4, entry 2). The alkyl $\alpha$-hydroxyketones $\mathbf{4 - 8}$ were also reduced to the corresponding tetraols 14-18 with excellent yields (92-97\%) (Table 4, entries 3-7). The $\alpha$-hydroxyketone $\mathbf{9}$, bearing the citronellal chain, was also converted to the tetraol 19 with $96 \%$ yield, with concomitant reduction of the double bond (Table 4, entry 8). Finally, $\alpha$ hydroxyketones 10-11 were also reduced to the corresponding tetraols 20-21 with good yields (Table 4, entries 9-10). 
Table 4. Reduction of $\alpha$-hydroxyketones to tetraols. ${ }^{a}$

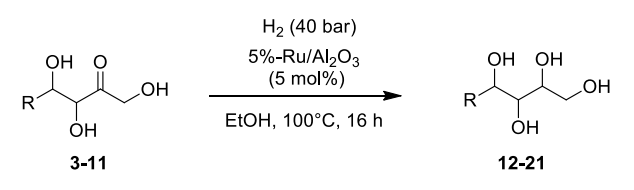

\begin{tabular}{|c|c|c|c|c|}
\hline Entry & Aldol & Tetraol & & Yield $^{b}(\%)$, d.r. \\
\hline 1 & 3 & & 12 & $95(56: 44)$ \\
\hline $2^{d}$ & 3 & & 13 & $94(50: 50)$ \\
\hline 3 & 4 & & 14 & $97(55: 45)$ \\
\hline 4 & 5 & & 15 & $93(50: 50)$ \\
\hline 5 & 6 & & 16 & $94(25: 75)$ \\
\hline 6 & 7 & & 17 & $92(22: 78)$ \\
\hline 7 & 8 & & 18 & $94(35: 65)$ \\
\hline 8 & 9 & & 19 & $96(50: 50)$ \\
\hline 9 & 10 & & 20 & $79(60: 40)$ \\
\hline 10 & 11 & & 21 & $\begin{array}{l}87 \text { (mixture of } 8 \\
\text { isomers) }\end{array}$ \\
\hline
\end{tabular}

${ }^{a}$ Reaction conditions: $30 \mathrm{~mL}$ stainless steel autoclave, aldol $(500 \mathrm{mg})$, hydrogen pressure (40 bar), 5\%-Ru/ $\mathrm{Al}_{2} \mathrm{O}_{3} \quad(5 \mathrm{~mol} \%)$, EtOH $(12 \mathrm{~mL}), 100^{\circ} \mathrm{C}, 16$ hours. ${ }^{b}$ Isolated yields. ${ }^{c}$ Diastereoisomer ratios were determined by NMR. ${ }^{d}$ Reaction conditions: hydrogen pressure $(5$ bar), $30^{\circ} \mathrm{C}, 24$ hours. 
Overall, this two-step aldolisation/reduction procedure gave access to a range of tetraols with good atom-economy and satisfying yields considering the difficulty to isolate such species. So far, these methods do not present any diastereoselectivity, thus giving a mixture of products. In fact, this is not really a problem since nonionic surfactants are generally marketed as mixtures of oligomers or isomers since they exhibit better functional properties. ${ }^{40}$ In particular, when a welldefined surfactant has a high $\mathrm{Krafft}$ point $\left(\mathrm{T}>25^{\circ} \mathrm{C}\right)$, it does not behave as an amphiphile at room temperature. On the other hand, when mixed with oligomers or isomers, its apparent Krafft point decreases and the surfactant can then develop its surface-active properties at room temperature (vide infra). ${ }^{41,42}$

\section{Physicochemical properties of tetraols}

Alkyl 1,2,3,4-tetraols have only been reported for the preparation of natural product analogues ${ }^{43}$ or for the synthesis of liquid crystals. ${ }^{44}$ However, to the best of our knowledge, the amphiphilic properties of such compounds have never been investigated. Consequently, the physicochemical properties, i.e. Critical Micelle Concentration (CMC) and Krafft point, of these new amphiphilic tetraols were determined. Only the mixtures of isomers were considered for this study as the solubility of pure isomers is usually lower than those the mixtures. Their amphiphilicity was also assessed by using PIT-slope method and the results were used to formulate three phase microemulsion systems. The surface tension of all tetraols in aqueous solutions was measured by the Wilhelmy plate method using a platinum rod as probe. Tetraol $\mathbf{1 2}$ bearing a cyclohexyl group as hydrophobic chain and tetraol $\mathbf{1 3}$ bearing the corresponding phenyl group were first 
compared. Their surface tension profiles are shown in figure 2 and the characteristic values are summarized in Table 5.

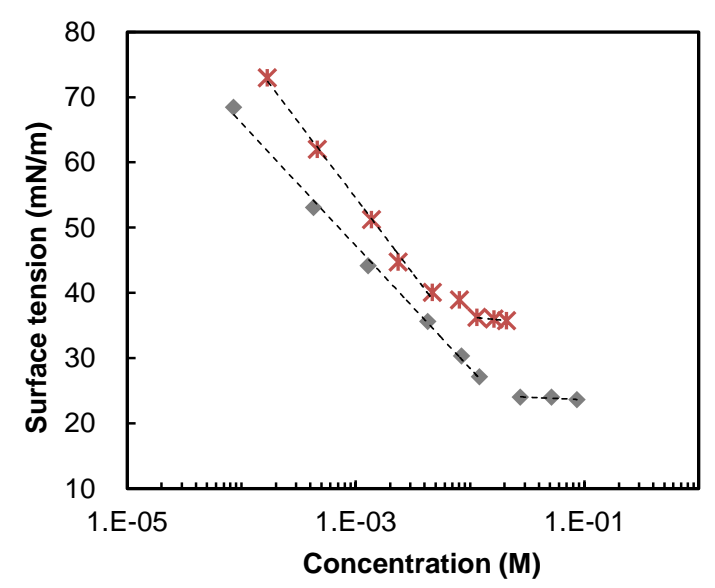

Figure 2. Surface tension vs. concentration of tetraol surfactants. ( $\diamond)$ tetraol 12 with cyclohexyl group, (*) tetraol 13 with phenyl group.

Table 5. Critical Micelle Concentration (CMC) and surface tension $\left(\gamma_{\mathrm{SAT}}\right)$ values of tetraols. ${ }^{a}$

\begin{tabular}{lllll} 
Entry & Tetraol & $\begin{array}{l}\mathrm{CMC}^{b} \\
(\mathrm{mmol} / \mathrm{L})\end{array}$ & $\begin{array}{l}\gamma_{\mathrm{sat}^{b}} \\
(\mathrm{mN} / \mathrm{m})\end{array}$ \\
\hline 1 & cyclohexyl-C2-tetraol & $\mathbf{1 2}$ & 17 & 25.8 \\
2 & phenyl-C2-tetraol & $\mathbf{1 3}$ & 5.9 & 35.7 \\
3 & $\mathrm{C}_{3}$-tetraol & $\mathbf{1 4}$ & 100 & 26.5 \\
4 & $\mathrm{C}_{5}$-tetraol & $\mathbf{1 5}$ & 44 & 26.7 \\
5 & C $_{7}$-tetraol & $\mathbf{1 6}$ & 7.9 & 26.1 \\
6 & C9-tetraol $_{7}$ & $\mathbf{1 7}$ & 1.6 & 24.0 \\
7 & C $_{11}$-tetraol & $\mathbf{1 8}$ & 0.26 & 23.7 \\
8 & iC9-tetraol & $\mathbf{1 9}$ & 3.6 & 23.3
\end{tabular}


nd

a Tetraols were used as mixtures of isomers as obtained through the aldolisation/reduction sequence. ${ }^{b}$ Determined by tensiometry. nd: not determined.

The cyclohexane derivative $\mathbf{1 2}$ exhibits a higher CMC than its phenyl counterpart $\mathbf{1 3}$, whereas, the surface tension of water could be decreased much lower (Table 5, entries 1-2). Hatzopoulos et al. reported this trend comparing very short phenyl and cyclohexyl n-alkanoates $(\mathrm{n}=0$ and 1). ${ }^{45}$ For these molecules the hydrophobic contribution of the phenyl group is higher than the cyclohexyl compound, as observed for the compounds 12 and 13. Tetraols 14-18 bearing linear alkyl chain with increasing length were next considered. All these linear surfactants show a decreasing trend of surface tension and a plateau value $\left(\gamma_{\text {sat }}\right)$ around $25 \mathrm{mN} / \mathrm{m}$ (Figure 3 ) (Table 5, entries 3-7). The best results were obtained with tetraol 18 bearing a C11 alkyl chain, giving a CMC value of $0.26 \mathrm{mmol} / \mathrm{L}$ and a $\gamma_{\text {sat }}$ of $23.7 \mathrm{mN} / \mathrm{m}$ (Table 5, entry 7).

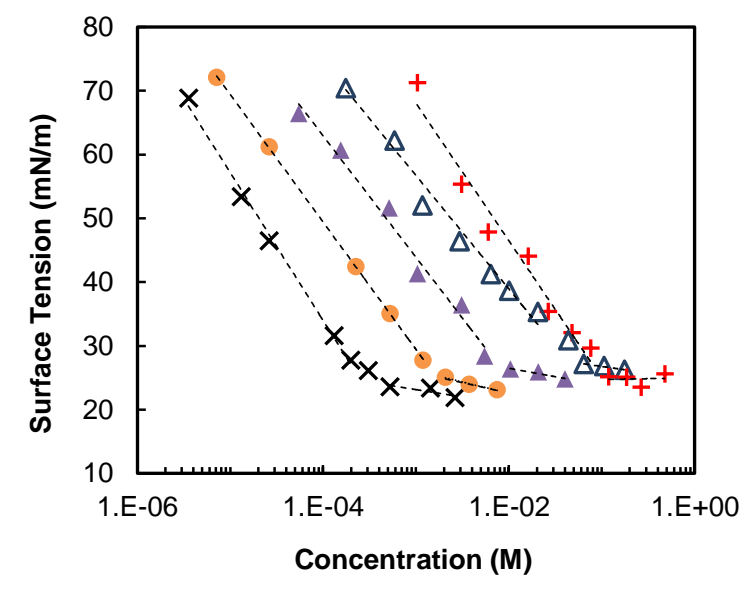

Figure 3. Surface tension vs. concentration of linear alkyl tetraol surfactants. $(X) \mathrm{C}_{11}$-tetraol 18,

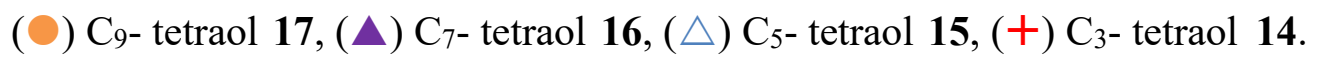


The CMC of tetraols 14-18 was plotted against the alkyl chain length (N) (Figure 4). The dotted line represents the linear behaviour described by the empirical equation proposed by Klevens: ${ }^{46,47} \log (\mathrm{CMC})=\mathrm{A}-\mathrm{BN}$. In that case, coefficients A and B (calculated from figure 4) are 0.50 and 0.37 , respectively. The shorter tetraol 14 does not follow the tendency observed for the longer tetraols 15-18. Even if the tensiometric profile presents a clear brake, the structure of tetraol 14 matches better with an hydrotrope than with a surfactant.

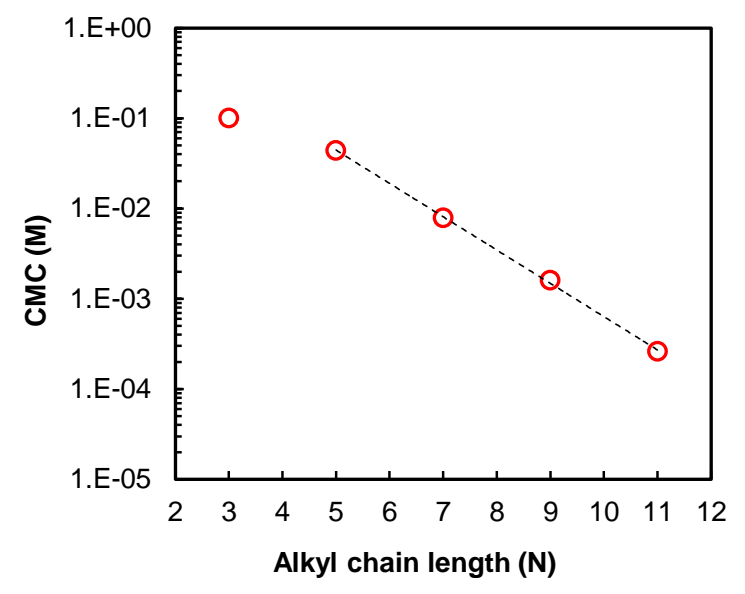

Figure 4. Critical Micelle Concentration of alkyl tetraols as function of the alkyl chain length $(\mathrm{N})$.

Tetraol 19 bearing a branched alkyl chain exhibits a higher CMC than the linear compounds (Table 5, entry 8). Indeed, the surface tension profile of citronellal-derived tetraol 19 (Figure 5) is placed between the linear $\mathrm{C}_{7}$-tetraol $\mathbf{1 6}$ and $\mathrm{C}_{9}$-tetraol $\mathbf{1 7}$. This phenomenon has already been reported and is explained by the steric hindrance of the branched structure that difficult the micelles formation. The $\mathrm{CMC}$ of linear $\mathrm{C}_{8}$-tetraol was calculated using the Kleven's equation and was found to be approximately $3.4 \mathrm{mM}$, a very close value for $\mathrm{iC}_{9}$-tetraol $\mathbf{1 9}$. This result is fully in accordance with the rule proposed by Götte, ${ }^{48}$ that each branched carbon appears to have "one-half" effect of a carbon in the alkyl linear chain. 
The tensiometric profiles of tetraols $\mathbf{2 0}$ and $\mathbf{2 1}$ were compared with those of tetraol 17, bearing a $\mathrm{C}_{9}$ linear chain (Figure 5).

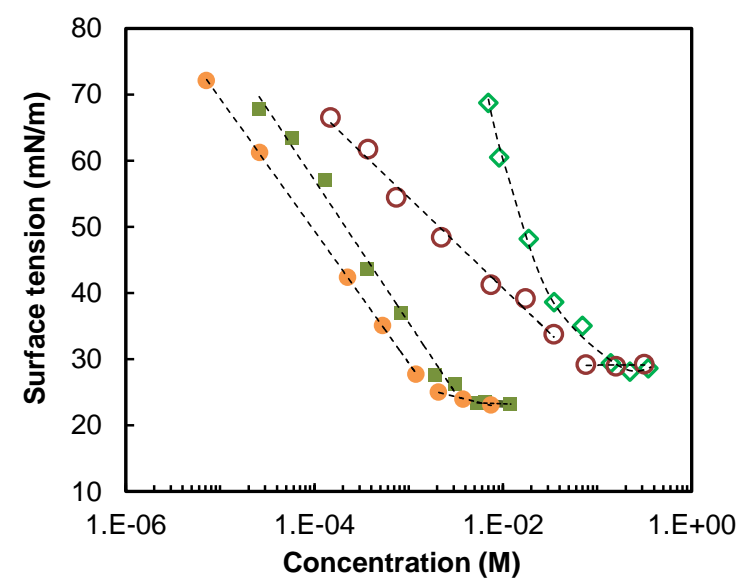

Figure 5. Surface tension vs. concentration of alkyl tetraol surfactants. (๑) $\mathrm{C}_{9}$-tetraol 17, (口) iC -tetraol 19, (O) ester-C 7 -tetraol 20, $(\diamond)$ THF-tetraol 21.

The presence of an ester group in $\mathbf{2 0}$ diminishes dramatically the lipophilic character at the end of the alkyl chain, thus increasing its CMC compared to the surfactant with the same alkyl chain, as described by Nardello et al. ${ }^{49}$ for sodium monoalkyl dicarboxylates. For furfural-derived tetraol 21, the decrease of the surface tension is weak and starts only a high concentration $\left(10^{-}\right.$ $\left.{ }^{2} \mathrm{M}\right)$, a typical behaviour for hydrotropes.

The Krafft point was next determined for tetraols 14-18 (Table 6). This parameter is considered of a practical point of view as the temperature above which a $1 \%$ wt. aqueous solution of surfactant is soluble. ${ }^{50}$ All these samples are mixtures of diastereomers and their behavior is complex, ${ }^{51}$ i.e the Krafft point of the two isomers $(\alpha$ and $\beta$ ) of alkyl glucopyranosides presents even $20^{\circ} \mathrm{C}$ of difference. ${ }^{52}$ 
Table 6. Krafft temperature for different tetraols. ${ }^{a}$

\begin{tabular}{llll} 
Entry & Tetraol & & Krafft Temperature $\left({ }^{\circ} \mathrm{C}\right)$ \\
\hline 1 & $\mathrm{C}_{3}$-tetraol & $\mathbf{1 4}$ & $<5$ \\
2 & $\mathrm{C}_{5}$-tetraol & $\mathbf{1 5}$ & $<5$ \\
3 & $\mathrm{C}_{7}$-tetraol & $\mathbf{1 6}$ & 60 \\
4 & C $_{9}$-tetraol & $\mathbf{1 7}$ & 65 \\
5 & C $_{11}$-tetraol & $\mathbf{1 8}$ & 83 \\
${ }^{a}$ Determined by observation. & &
\end{tabular}

This study shows that only short chain tetraols $\mathbf{1 4}$ and $\mathbf{1 5}$ are fully soluble at room temperature (Table 6, entries 1-2). However, other tetraols 16-18 with an alkyl chain length $>7$ carbons have a limited solubility (Table 6, entries 3-5). The sudden increase in Krafft temperature when the hydrophobic chain passes from $\mathrm{C}_{5}$ to $\mathrm{C}_{7}$ is probably due to relative proportions of the diastereoisomers which are equal to 50:50 and 25:75, respectively. Results from figure 3 reflect the typical surface tension profiles; however, several of the most concentrated solutions were indeed stable dispersions. One of the diastereoisomers is more soluble than the other and facilitates its solubilisation. When increasing the total concentration, the mixture partially precipitates. To improve its use at room temperature, hydrotropes could be added into the formulation.

The hydrophilic lipophilic balance of some of these surfactants was assessed by using the socalled PIT-slope method. ${ }^{53}$ This method allows classifying surfactants taking tetraethyleneglycol monodecyl ether $\left(\mathrm{C}_{10} \mathrm{E}_{4}\right)$ as reference. The phase inversion temperature (PIT) of a reference $3 \% \mathrm{C}_{10} \mathrm{E}_{4} / \mathrm{n}$-octane $/ 0.01 \mathrm{M} \mathrm{NaCl}_{(\mathrm{aq})}$ emulsion is followed by conductivity and the influence of adding an alkyl tetraol is quantified by the slope of the PIT values measured at several 
concentrations of the second surfactant. Figure 6 shows the increase or decrease of the PIT with the molar fraction $\mathrm{x}_{2}$ of the second surfactant in the mixture $\left(\mathrm{C}_{10} \mathrm{E}_{4}+\right.$ alkyl tetraol). The slope of several n-alkyl tetraethoxylated surfactants are also shown for comparison. Longer alkyl tetraols show a linear behavior whereas the shortest compound $\left(\mathrm{C}_{7}\right.$-tetraol 16) presents a less accurate linear match $\left(\mathrm{R}^{2}=0.97\right)$. The evolution of the PIT when adding the tetraols was quantified by the $\mathrm{dPIT} / \mathrm{dx}_{2}$ parameter that corresponds to the slope obtained from figure 6. The PIT-slope values are summarized in Table 7.

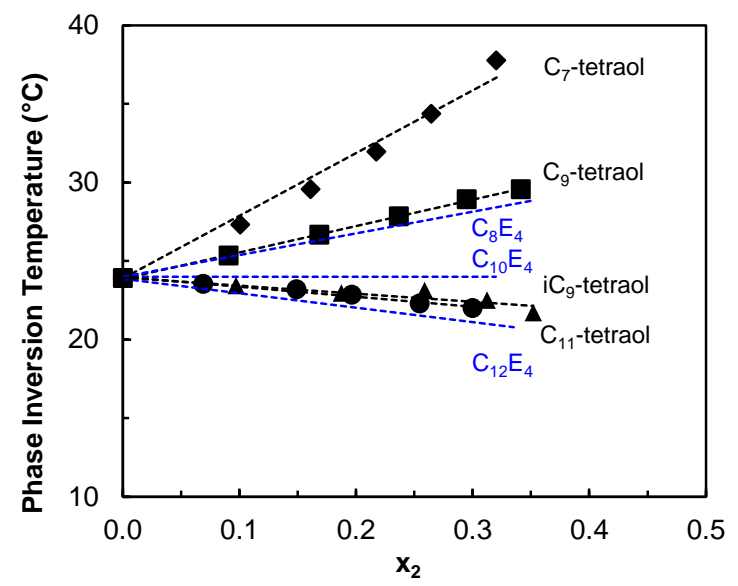

Figure 6. Phase inversion Temperature (PIT) vs. molar fraction $\mathrm{x}_{2}$ of added surfactant for the $3 \%$

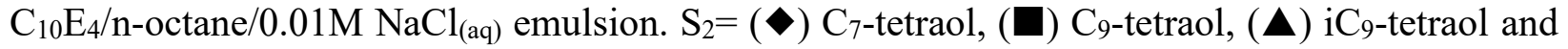
(O) $\mathrm{C}_{11}$-tetraol. The dotted lines indicate the linear fitting. $\mathrm{C}_{8} \mathrm{E}_{4}{ }^{54}$ and $\mathrm{C}_{12} \mathrm{E}_{4}{ }^{8}$ are shown for comparative purposes. 
Table 7. PIT-slope values expressed in ${ }^{\circ} \mathrm{C}\left(\mathrm{dPIT} / \mathrm{dx}_{2}\right)$ or ${ }^{\circ} \mathrm{C} / \mathrm{wt} . \%(\mathrm{dPIT} / \mathrm{dC})$ for alkyl tetraols and $\mathrm{C}_{\mathrm{i}} \mathrm{E}_{\mathrm{j}}$.

\begin{tabular}{lllll} 
Entry & Surfactant & & $\mathrm{dPIT} / \mathrm{dx}_{2}\left({ }^{\circ} \mathrm{C}\right)$ & $\mathrm{dPIT} / \mathrm{dC}\left({ }^{\circ} \mathrm{C} / \mathrm{wt}.\right)$ \\
\hline 1 & $\mathrm{C}_{7}$-tetraol & $\mathbf{1 6}$ & 43 & 14.8 \\
2 & $\mathrm{C}_{9}$-tetraol & $\mathbf{1 7}$ & 17 & 4.9 \\
3 & $\mathrm{C}_{8} \mathrm{E}_{4}$ & & 13.8 & 2.2 \\
4 & $\mathrm{C}_{10} \mathrm{E}_{4}$ & $($ reference $)$ & 0 & 0 \\
5 & $\mathrm{iC}_{9}$-tetraol & $\mathbf{1 9}$ & -5.1 & -1.5 \\
6 & $\mathrm{C}_{11}$-tetraol & $\mathbf{1 8}$ & -6.3 & -1.7 \\
7 & $\mathrm{C}_{12} \mathrm{E}_{4}$ & & -9.2 & -1.8
\end{tabular}

From the PIT-slope values, $\mathrm{C}_{11}$-tetraol 18 and $\mathrm{iC}_{9}$-tetraol 19 are the only surfactants more lipophilic than the $\mathrm{C}_{10} \mathrm{E}_{4}$ and more hydrophilic than $\mathrm{C}_{12} \mathrm{E}_{4}$, however the $\mathrm{C}_{9}$ and $\mathrm{C}_{7}$ tetraols $\mathbf{1 6}$ and 17 are clearly more hydrophilic than $\mathrm{C}_{10} \mathrm{E}_{4}$ and $\mathrm{C}_{8} \mathrm{E}_{4}$, respectively. In order to evaluate if the synthesized surfactants are able to give microemulsions without co-surfactant or salt, an oil scan was carried out. The alkanes are characterized by the number of carbons in the molecule (i.e. 8 for octane). For other oils such as esters, ethers or chloro-alkanes, the oil is characterized by an equivalent alkane carbon number EACN whose experimental determination is described elsewhere. ${ }^{55,56}$ The oil that allows obtaining a three phase behavior (Winsor III) ${ }^{57}$ for a non-ionic Surfactant/Oil/Water system at $25^{\circ} \mathrm{C}$ provides the so-called Preferred Alkane Carbon Number $(\mathrm{PACN})^{58}$ of the surfactant. This parameter is a scientifically founded version of the HLB empirical scale. Hydrophilic surfactants have low PACN, i.e. they need somewhat polar oils such as chloro or di-chloro alkanes to provide three phase behaviour. 
Hydrophobic surfactants have higher PACN and they could need oils as hexadecane to obtain a WIII behavior. Figure 6 showed that $\mathrm{C}_{9}$-tetraol has a hydrophilic-lipophilic balance close to the $\mathrm{C}_{8} \mathrm{E}_{4}$ behavior and their PACN must be equivalent. However, the high Krafft temperature of alkyl-tetraols does not allow the formulation of Alkyl Tetraol/Oils/Water microemulsion systems at $25^{\circ} \mathrm{C}$. The oil scan for the $\mathrm{C}_{9}$-tetraol was therefore carried out at $75^{\circ} \mathrm{C}$ (Figure 7). The lighter 1-chlorohexane is able to promote a Winsor II behavior in which the surfactant is preferentially in the oily phase in equilibrium with an excess water phase (Figure 7, left). For 1-chlorooctane and 1-chlorodecane, a third microemulsion phase is obtained in equilibrium with both, aqueous and oil excess phases (Figure 7, middle). Heavy oils decrease the affinity of the surfactant for the oily phase and promote Winsor I system (Figure 7, right).

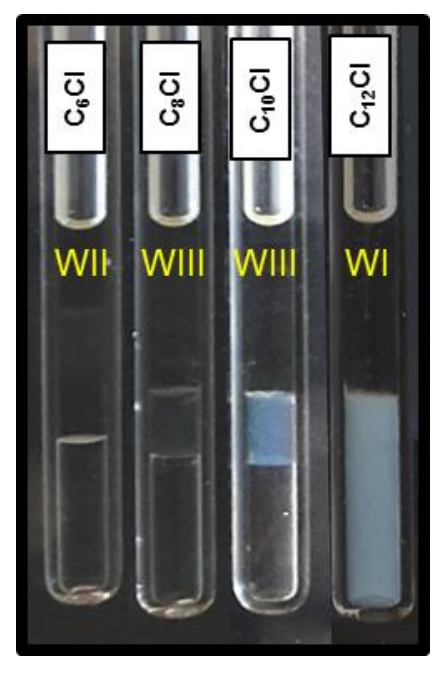

Figure 7. Oil scan performed for 3\% $\mathrm{C}_{9}$-tetraol/1-Chloro-alkane/Water systems after 2 days equilibration period at $75^{\circ} \mathrm{C}$.

When the temperature is increased up to $85^{\circ} \mathrm{C}$ the phase behavior changes since 1chlorododecane provides a Winsor III system. The alkyl tetraols hydrophilicity decreases when the temperature increases. Such as behavior was described by Stubenrauch et al. ${ }^{59}$ for alkyl 
glucosides. As these surfactants, $\mathrm{C}_{9}$-tetraol 17 allows formulate microemulsions at higher temperatures without adding cosurfactants for polar oils. However, to be used at room temperature or with linear alkanes, cosurfactants are required.

Finally, the CMC and the PIT-slope for $\mathrm{C}_{11}$-tetraol 18 was compared with of other polyol surfactants (Table 8).

Table 8. Comparison with other available polyol surfactants.

\begin{tabular}{|c|c|c|c|c|}
\hline Entry & Surfactant & $\begin{array}{l}\mathrm{CMC}^{a} \\
(\mathrm{mmol} / \mathrm{L})\end{array}$ & $\gamma_{\mathrm{sat}}{ }^{a}(\mathrm{mN} / \mathrm{m})$ & $\begin{array}{l}\mathrm{dPIT} / \mathrm{dC}^{b} \\
\left({ }^{\circ} \mathrm{C} / \mathrm{wt} . \%\right)\end{array}$ \\
\hline 1 & $\begin{array}{l}{ }_{\mathrm{HO}}^{\mathrm{HO}} \underbrace{}_{\mathrm{OH}} \mathrm{XY}_{10} \\
\mathrm{C}_{12} \text {-glucoside } \\
\left(\mathrm{C}_{12} \mathrm{Glu}\right)\end{array}$ & $0.19^{60}$ & $36^{60}$ & $5.9^{53}$ \\
\hline 2 & $\begin{array}{l}\mathrm{C}_{12} \text {-sorbitan ester } \\
(\mathrm{Span} 20)\end{array}$ & $0.041^{10}$ & $31^{10}$ & $-12.1^{61}$ \\
\hline 3 & $\begin{array}{l}\mathrm{C}_{12} \text {-diglycerol } \\
\left(\mathrm{C}_{12} \mathrm{Gly}_{2}\right)\end{array}$ & $0.031^{62}$ & $27^{62}$ & $1^{53}$ \\
\hline 4 & & 0.26 & 23.7 & -1.7 \\
\hline
\end{tabular}

${ }^{a}$ Determined by tensiometry. ${ }^{b}$ Determined by the PIT-slope method. 
Even with one carbon less than other surfactants, $\mathbf{1 8}$ is as efficient as the corresponding dodecylglucoside in terms of its CMC, but 5-8 times less efficient than dodecanoylsorbitan (SPAN 20) or 1-O-dodecyldiglycerol $\left(\mathrm{C}_{12} \mathrm{Gly}_{2}\right)$. Interestingly, the tetraol surfactant has the highest effectiveness since it decreases the surface tension as low as $23.7 \mathrm{mN} / \mathrm{m}$. In 1,2,3,4tetraols, the polar head bearing 4 hydroxyl groups in the first 4 carbons is shorter than the other ones and there is no heteroatom between the alkyl chain and the polar head. This difference could be at the origin of its enhanced effectiveness. ${ }^{63}$ From the PIT-slope values, the hydrophilicity ranking is $\mathrm{C} 12 \mathrm{Glu}>\mathrm{C} 12 \mathrm{Gly} 2>\mathrm{C} 11$-tetraol $>$ Span 20 . These results are fully consistent with the structure of these surfactants.

\section{CONCLUSIONS}

In conclusion, we have developed a method for the aldolisation of unprotected 1,3dihydroxyacetone (DHA) with a range of (bio-based) non-aromatic aldehydes. The reaction is promoted by trimethylamine under mild conditions $\left(20^{\circ} \mathrm{C}\right)$ in a mixture of water/EtOH to give $\alpha$ hydroxyketones with $29-70 \%$ isolated yields. The $\alpha$-hydroxyketones were reduced under hydrogen to give the corresponding tetraols with $79-97 \%$ isolated yields. The amphiphilic properties of these new $\mathrm{C}-\mathrm{C}$ bond linked tetraol surfactants have been studied by the measurement of their $\mathrm{CMC}$ and Krafft point and their hydrophilicy has been evaluated using the PIT-slope method. These studies have shown that this new type of surfactants exhibits a high effectiveness to reduce the surface tension of water. Finally, $\mathrm{C}_{9}$-tetraol is able to produce a microemulsion with three phase behaviour at high temperatures. 


\section{EXPERIMENTAL SECTION}

\section{General information}

All reagents were used as received from the chemical company. 1,3-Dihydroxyacetone (DHA, dimer, $97 \%$ purity) was purchased from Alfa-Aesar. Butyaldehye, hexanal, octanal, decanal, dodecanal and hydrocinamaldehyde were supplied by Sigma-Aldrich or Alfa-Aesar, and were purified by distillation before use (except dodecanal). Amberlyst A26 (OH), ion exchange resin, A17361 was bought from Alfa-Aesar. Pd (5\% on activated wood carbon, reduced, dry, Escat ${ }^{\mathrm{TM}}$ 1431), ruthenium (5\% on carbon), ruthenium (5\% on alumina) were purchased from Strem Chemicals.

\section{General procedure for the aldolisation of DHA.}

In a sealed tube, 1,3-dihydroxyacetone (DHA) 1 (1.0 g, $11.1 \mathrm{mmol}, 5$ equiv.) was dissolved in a mixture of EtOH $(5.5 \mathrm{~mL})$ and distilled water $(5.5 \mathrm{~mL})$. The aldehyde $(2.2 \mathrm{mmol}, 1$ equiv.) was added, followed by the homogeneous catalyst $(1.1 \mathrm{mmol}, 0.5$ equiv.) or the heterogeneous catalyst Amberlyst A26(OH) (100 wt \%/DHA). The mixture was stirred (800 rpm) at room temperature $\left(20^{\circ} \mathrm{C}\right)$ for 4 hours. After reaction, the solvent was removed in vacuum, and the residue was purified by column chromatography $\left(\mathrm{CH}_{2} \mathrm{Cl}_{2} / \mathrm{MeOH} 40: 1 \rightarrow 25: 1\right)$ to give $\alpha$ hydroxyketones 3-11. All details of the chemical characterizations $\left({ }^{1} \mathrm{H} \mathrm{NMR},{ }^{13} \mathrm{C}\right.$ NMR, MS) are given in the ESI.

\section{General procedure for the hydrogenation of $\alpha$-hydroxyketones to tetraols.}

In a $35-\mathrm{mL}$ stainless steel autoclave, the $\alpha$-hydroxyketone ( $5 \mathrm{mmol}, 1$ equiv.) was dissolved in $\mathrm{EtOH}(25 \mathrm{~mL}) \cdot \mathrm{Ru} / \mathrm{Al}_{2} \mathrm{O}_{3}(5 \mathrm{wt} \% \mathrm{Ru}, 0.25 \mathrm{mmol}, 5 \mathrm{~mol} \%$ in $\mathrm{Ru})$ was added. The autoclave was 
flushed with hydrogen (10 bar) for 3 times. The solution was stirred $(800 \mathrm{rpm})$ under 40 bar hydrogen at $100^{\circ} \mathrm{C}$ for 16 hours. After cooling to room temperature, the reaction mixture was filtered (Millipore Durapore filter $0.01 \mu \mathrm{m}$ ) and washed with EtOH. The filtrate was concentrated under vacuum to give tetraol products 12-21. All details of the chemical characterizations $\left({ }^{1} \mathrm{H}\right.$ NMR, ${ }^{13} \mathrm{C}$ NMR, MS $)$ are given in the ESI.

\section{General procedure for measuring the CMC and the Krafft Point}

The surface tensions were measured at room temperature with a K100MK2 Krüss tensiometer using a platinum rod as probe. Measurements were made on $2 \mathrm{~mL}$ samples. The surface tension of pure water was first measured to calibrate and then different concentrations of the same sample were measured. When the surface tension was stable (standard deviation of the 5 final measurements lower than $0.15 \mathrm{mN} \mathrm{m}-1$ ), record the value as the first result. The measurement was repeated twice or 3 times to get an average value for each sample.

The Krafft point was determined by increasing the temperature of a $1 \%$ wt. surfactant solution. It corresponds to the temperature at which the precipitated surfactant became soluble.

\section{PIT-slope method}

Before the experiment, $10 \mathrm{~mL}$ of the $\mathrm{C}_{10} \mathrm{E}_{4} / \mathrm{n}$-Octane/Water system was prepared in a $20 \mathrm{~mL}$ vial $(\mathrm{d}=2.5 \mathrm{~cm}, \mathrm{~h}=5.5 \mathrm{~cm})$ by pouring a mass $\mathrm{m}_{\mathrm{w}}(4.25 \mathrm{~g})$ of $\mathrm{NaCl} 10^{-2} \mathrm{M}$ aqueous brine, a mass $\mathrm{m}_{\mathrm{o}}$ ( $4.25 \mathrm{~g})$ of $n$-octane, and then a mass of surfactant $\mathrm{S}_{1}=\mathrm{C}_{10} \mathrm{E}_{4}(0.263 \mathrm{~g})$. This system was handshaken during a few seconds and left to pre-equilibrate $24 \mathrm{~h}$ at room temperature. A first heatingcooling cycle was performed and then the second surfactant $\mathrm{S}_{2}$ was added (mass $\mathrm{m}_{\mathrm{S} 2}$ ). The amount of $\mathrm{C}_{10} \mathrm{E}_{4}$ was then adjusted to $\mathrm{m}_{\mathrm{S} 1}$ so that the proportion of $\mathrm{S}_{1}$ surfactant remains constant 
at 3 wt. $\%$ of the whole system in all experiments. Equation 1 defines $\mathrm{S}_{2}$ surfactant molar fraction in the surfactant mixture.

$$
x_{2}=\frac{m_{S 2} / M W_{2}}{m_{S 1} / M W_{1}+m_{S 2} / M W_{2}}
$$

The water weight fraction $f_{w}$ defined by equation 2 is 0.5 in all systems.

$$
f_{w}=\frac{m_{w}}{m_{w}+m_{o}}
$$

During the whole experiment, the system was kept under continuous stirring using a crossshaped magnetic stirrer $(1.8 \mathrm{~cm}$ diameter $)$ at $500 \mathrm{rpm}$. The sample was then subjected to two heating-cooling cycles at a rate of $1^{\circ} \mathrm{C} / \mathrm{min}$. Temperature-controlled water from a HUBER Ministat 125 bath circulated through the vessel in which the vial was introduced. The conductivity and temperature were simultaneously measured by a Radiometer Analytical CDM 210 conductimeter fitted with a CDC741T platinized platinum probe. The software used was custom written in a Labview 7.1 National Instruments platform. Temperature and conductivity profiles for two heating-cooling cycles were obtained as a function of time. The parallel tangent method was used to determine the PIT. The reported value is the average of the four determined temperatures.

\section{Oil scan}

1g-samples were prepared in 2-mL vials by weighting successively water (W), oil (O) and surfactant $(\mathrm{S})$. In all samples, the water/oil ratio equals 1 , i.e. the water weight fraction $\mathrm{f}_{\mathrm{w}}$ equals 0.5. The surfactant/oil/water systems are then gently mixed to favour the contact of phases while avoiding emulsification. The vials are then placed in a thermostatic bath HUBER Ministat 125 at 
$75^{\circ} \mathrm{C} \pm 0.1^{\circ} \mathrm{C}$ until phase separation and equilibrium are reached. The determination of the phase behaviour is determined by visual inspection in order to classify the systems according to Winsor nomenclature.

\section{ASSOCIATED CONTENT}

Supporting Information. The supporting information contains the general procedures, the characterization data of $\alpha$-hydroxyketones and tetraols, as well as ${ }^{1} \mathrm{H}$ and ${ }^{13} \mathrm{C}$ NMR spectra of all compounds.

\section{AUTHOR INFORMATION}

\section{Corresponding Authors}

*E-mail:nicolas.duguet@univ-lyon1.fr

ORCID

Nicolas Duguet: 0000-0002-9425-7450

*E-mail: marc.lemaire.chimie@univ-lyon1.fr

\section{Notes}

The authors declare no competing financial interest.

\section{ACKNOWLEDGMENT}

The China Scholarship Council (CSC) is warmly thanked for a Ph.D. grant to B. Z.

\section{ABBREVIATIONS}


DHA, 1,3-dihydroxyacetone; APG, alkyl (poly)glycoside; FSA, D-fructose-6-phosphate aldolase; HCA, hydrocinnamaldehyde; 4-DMAP, 4-dimethylaminopyridine, DABCO, 1,4diazabicyclo[2.2.2]octane; CMC, Critical Micelle Concentration; PIT, phase inversion temperature; EACN, equivalent alkane carbon number; PACN, Preferred Alkane Carbon Number.

\section{REFERENCES}

1 Foley, P.; Kermanshahi, A.; Beach, E. S.; Zimmerman, J. B. Derivation and synthesis of renewable surfactants. Chem. Soc. Rev. 2012, 41, 1499-1518, DOI 10.1039/C1CS15217C.

2 Hill, K. in Surfactants from Renewable Resources, ed. Kjellin, M. and Johansson, I., John Wiley \& Sons, Ltd., 2010.

3 Capderou, M.; Pale, P. Valorisation of agricultural resources: synthesis of green tensioactives agents from carbohydrates. C. R. Chim. 2004, 7, 607-610, DOI 10.1016/j.crci.2004.02.010.

4 Lichtenthaler, F. W.; Peters, S. Carbohydrates as green raw materials for the chemical industry. C. R. Chim. 2004, 7, 65-90, DOI 10.1016/j.crci.2004.02.002.

5 von Rybinski, W. Alkyl glycosides and polyglycosides. Curr. Opin. Colloid Interface Sci. 1996, $1,587-597$, DOI 10.1016/S1359-0294(96)80096-3.

6 Mutua, L. N.; Akoh, C. C. Synthesis of alkyl glycoside fatty acid esters in non-aqueous media byCandida sp. lipase. J. Am. Oil Chem. Soc. 1993, 70, 43-46, DOI 10.1007/BF02545365.

7 Garti, N.; Clement, V.; Leser, M.; Aserin, A.; Fanun, M. Sucrose ester microemulsions. J. Mol. Liq. 1999, 80, 253-296, DOI 10.1016/S0167-7322(99)80010-5. 
8 Murdan, S.; Gregoriadis, G.; Florence, A. T. Novel sorbitan monostearate organogels. J. Pharm. Sci. 1999, 88, 608-614, DOI 10.1021/JS980342R.

9 Sutter, M.; Da Silva, E.; Duguet, N.; Raoul, Y.; Métay, E.; Lemaire, M. Glycerol ether synthesis: a bench test for green chemistry concepts and technologies. Chem. Rev. 2015, 115, 8609-8651, DOI 10.1021/cr5004002.

10 Gozlan, C.; Deruer, E.; Duclos, M.-C.; Molinier, V.; Aubry, J.-M.; Redl, A.; Duguet, N.; Lemaire, M. Preparation of amphiphilic sorbitan monoethers through hydrogenolysis of sorbitan acetals and evaluation as bio-based surfactants. Green Chem. 2016, 18, 19942004, DOI 10.1039/c5gc02131f.

11 Belmessieri, D.; Gozlan, C.; Duclos, M.-C.; Dumitrescu, O.; Lina, G.; Redl, A.; Duguet, N.; Lemaire, M. Dodecyl sorbitan ethers as antimicrobials against Gram-positive bacteria. Bioorg. Med. Chem. Lett. 2017, 27, 4660-4663, DOI 10.1016/j.bmcl.2017.09.015.

12 Gozlan, C.; Lafon, R.; Duguet, N.; Redl, A.; Lemaire, M. Catalytic reductive cleavage of methyl $\alpha$-D-glucoside acetals to ethers using hydrogen as a clean reductant. RSC Adv. 2014, 4, 50653-50661, DOI 10.1039/c4ra09350j.

13 Belmessieri, D.; Gozlan, C.; Duclos, M.-C.; Molinier, V.; Aubry, J.-M.; Dumitrescu, O.; Lina, G.; Redl, A.; Duguet, N.; Lemaire, M. Synthesis, surfactant properties and antimicrobial activities of methyl glycopyranoside ethers. Eur. J. Med. Chem. 2017, 128, 98-106, DOI 10.1016/j.ejmech.2017.01.038.

14 Rodrigues, F.; Canac, Y.; Lubineau, A. A convenient, one-step, synthesis of $\beta-C$ glycosidic ketones in aqueous media. Chem. Commun. 2000, 2049-2050, DOI 10.1039/b006642g. 
15 Foley, P. M.; Phimphachanh, A.; Beach, E. S.; Zimmerman, J. B.; Anastas, P. T. Linear and cyclic $C$-glycosides as surfactants. Green Chem. 2011, 13, 321-325, DOI $10.1039 / \mathrm{c} 0 \mathrm{gc} 00407 \mathrm{c}$.

16Enders, D.; Voith, M.; Lenzen, A. The dihydroxyacetone unit-A versatile $\mathrm{C}_{3}$ building block in organic synthesis. Angew. Chem. Int. Ed. 2005, 44, 1304-1325, DOI 10.1002/anie.200400659.

17 Painter, R. M.; Pearson, D. M.; Waymouth, R. M. Selective catalytic oxidation of glycerol to dihydroxyacetone. Angew. Chem., Int. Ed. 2010, 49, 9456-9459, DOI 10.1002/anie.201004063.

18 Rocha-Martin, J.; Acosta, A.; Berenguer, J.; Guisan, J. M.; Lopez-Gallego, F. Selective oxidation of glycerol to 1,3-dihydroxyacetone by covalently immobilized glycerol dehydrogenases with higher stability and lower product inhibition. Bioresour. Technol. 2014, 170, 445-453, DOI 10.1016/j.biortech.2014.07.116.

19 Pagliaro, M.; Ciriminna, R.; Kimura, H.; Rossi, M.; Della Pina, C. From glycerol to value-added products. Angew. Chem., Int. Ed. 2007, 46, 4434-4440, DOI 10.1002/anie.200604694.

20Zhou, C.-H.; Beltramini, J. N.; Fan, Y.-X.; Lu, G. Q. Chemoselective catalytic conversion of glycerol as a biorenewable source to valuable commodity chemicals. Chem. Soc. Rev. 2008, 37, 527-549, DOI 10.1039/b707343g.

21 van Herk, T.; Hartog, A. F.; Schoemaker, H. E.; Wever, R. Simple enzymatic in situ generation of dihydroxyacetone phosphate and its use in a cascade reaction for the production of carbohydrates: Increased efficiency by phosphate cycling. J. Org. Chem. 2006, 71, 6244-6247, DOI 10.1021/jo060644a. 
22 Moreno, I. S.; Iturrate, L.; Doyaguez, E. G.; Martinez, J. A.; Mayoralas, A. F.; Junceda, E. G. Activated $\alpha, \beta$-unsaturated aldehydes as substrate of dihydroxyacetone phosphate (DHAP)-dependent aldolases in the context of a multienzyme system. Adv. Synth. Catal. 2009, 351, 2967-2975, DOI 10.1002/adsc.200900603.

23 Szekrenyi, A.; Soler, A.; Garrabou, X.; Helaine, C. G.; Parella, T.; Joglar, J.; Lemaire, M.; Bujons, J.; Clapes, P. Engineering the donor selectivity of D-fructose-6-phosphate aldolase for biocatalytic asymmetric cross-aldol additions of glycolaldehyde. Chem. Eur. J. 2014, 20, 12572-12583, DOI 10.1002/chem.201403281.

24Rale, M.; Schneider, S.; Sprenger, G. A.; Samland, A. K.; Fessner, W.-D. Broadening deoxysugar glycodiversity: natural and engineered transaldolases unlock a complementary substrate space. Chem. Eur. J. 2011, 17, 2623-2632, DOI 10.1002/chem.201002942.

25 Concia, A. L.; Lozano, C.; Castillo, J. A.; Parella, T.; Joglar, J.; Clapes, P. D-Fructose-6phosphate aldolase in organic synthesis: cascade chemical-enzymatic preparation of sugar-related polyhydroxylated compounds. Chem. Eur. J. 2009, 15, 3808-3816, DOI 10.1002/chem.200802532.

26 Córdova, A.; Notz, W.; Barbas III, C. F. Direct organocatalytic aldol reactions in buffered aqueous media. Chem. Commun. 2002, 3024-3025, DOI 10.1039/b207664k.

27 Kofoed, J.; Reymond, J. L.; Darbre, T. Prebiotic carbohydrate synthesis: zinc-proline catalyzes direct aqueous aldol reactions of $\alpha$-hydroxy aldehydes and ketones. Org. Biomol. Chem. 2005, 3, 1850-1855, DOI 10.1039/B501512J. 
28 Luo, S. Z.; Xu, H.; Zhang, L.; Li, J. Y.; Cheng, J. P. Highly enantioselective direct synand anti-aldol reactions of dihydroxyacetones catalyzed by chiral primary amine catalysts. Org. Lett. 2008, 10, 653-656, DOI 10.1021/o1703023t.

29 Markert, M.; Mulzer, M.; Schetter, B.; Mahrwald, R. Amine-catalyzed direct aldol addition. J. Am. Chem. Soc. 2007, 129, 7258-7259, DOI 10.1021/ja071926a.

30 Ramasastry, S. S. V.; Albertshofer, K.; Utsumi, N.; Barbas III, C. F. Water-compatible organocatalysts for direct asymmetric syn-aldol reactions of dihydroxyacetone and aldehydes. Org. Lett. 2008, 10, 1621-1624, DOI 10.1021/o18002833.

31 Fanton, J.; Camps, F.; Castillo, J. A.; Hélaine, C. G.; Lemaire, M.; Charmantray, F.; Hecquet, L. Enzymatic and organocatalyzed asymmetric aldolization reactions for the synthesis of thiosugar scaffolds. Eur. J. Org. Chem. 2012, 203-210, DOI 10.1002/ejoc.201101137.

32 Kofoed, J.; Darbre, T.; Reymond, J. L. Dual mechanism of zinc-proline catalyzed aldol reactions in water. Chem. Commun. 2006, 1482-1484, DOI 10.1039/b600703a.

33 List, B.; Lerner, R. A.; Barbas III, C. F. Proline-catalyzed direct asymmetric aldol reactions. J. Am. Chem. Soc. 2000, 122, 2395-2396, DOI 10.1021/ja994280y.

34 Louis, K.; Vivier, L.; Clacens, J.-M.; Brandhorst, M.; Dubois, J.-L.; De Oliveira Vigier, K.; Pouilloux, Y. Sustainable route to methyl-9-hydroxononanoate (polymer precursor) by oxidative cleavage of fatty acid methyl ester from rapeseed oil. Green Chem. 2014, 16, 96-101, DOI 10.1039/c3gc41491d.

35 Omonov, T. S.; Kharraz, E.; Foley, P.; Curtis, J. M. The production of biobased nonanal by ozonolysis of fatty acids. $R S C A d v . \mathbf{2 0 1 4}, 4,53617-53627$, DOI 10.1039/c4ra07917e. 
36 Deruer, E.; Duguet, N.; Lemaire, M. Thiazolylidene-catalysed cleavage of methyl oleatederived $\alpha$-hydroxyketone to the corresponding free aldehydes. ChemSusChem 2015, 8 , 2481-2486, DOI 10.1002/cssc.201500462.

37 Karinen, R.; Vilonen, K.; Niemel, M. Biorefining: Heterogeneously catalyzed reactions of carbohydrates for the production of furfural and hydroxymethylfurfural. ChemSusChem 2011, 4, 1002-1016, DOI 10.1002/cssc.201000375.

38 Liu, C.; Carraher, J. M.; Swedberg, J. L.; Herndon, C. R.; Fleitman, C. N.; Tessonnier, J.P. Selective base-catalyzed isomerization of glucose to fructose. ACS Catal. 2014, 4, 4295-4298, DOI 10.1021/cs501197w.

39 Chen, Y.; Ren, X.; Wei, Q.; Guo, J. Conversion of undaria pinnatifida residue to glycolic acid with recyclable methylamine in low temperature hydrothermal liquefaction. Bioresour. Technol. 2016, 221, 477-484, DOI 10.1016/j.biortech.2016.09.073.

40 Shinoda, K.; Saito, H.; Arai, H. The effect of the size and the distribution of the oxyethylene chain lengths of nonionic emulsifiers on the stability of emulsions. J. Colloid Interface Sci. 1971, 35, 624-630, DOI 10.1016/0021-9797(71)90220-7.

41 Huibers, P. D.; Shah, D. O. Evidence for synergism in nonionic surfactant mixtures: enhancement of solubilization in water-in-oil microemulsions. Langmuir 1997, 13, 57625765, DOI 10.1021/la962108r.

42 Antón, R. E.; Andérez, J. M.; Bracho, C.; Vejar, F.; Salager, J. L. Practical surfactant mixing rules based on the attainment of microemulsion-oil-water three-phase behavior systems. In: Narayanan R. (eds) Interfacial Processes and Molecular Aggregation of Surfactants. Advances in Polymer Science, 2008, vol 218. Springer, Berlin, Heidelberg. 
43 Borkar, S. R.; Manjunath, B. N.; Balasubramaniam, S.; Aidhen, I. S. Convenient synthesis of D- and L-xylo-1,2,3,4-alkane tetrols from a D-gluco-configured common building block. Carbohydr. Res. 2012, 358, 23-30, DOI 10.1016/j.carres.2012.06.005.

44 Dahlhoff, W. V. Amphiphilic carbohydrate-based mesogens, VIII. A facile synthetic route to mesogenic L-ribo-1,2,3,4-alkanetetrols. Liebigs Ann. Chem. 1992, 2, 109-113, DOI 10.1002/jlac.199219920122.

45 Hopkins Hatzopoulos, M.; Eastoe, J.; Dowding, P. J.; Grillo, I.; Demé, B.; Rogers, S. E.; Heenan, R.; Dyer, R. Effects of structure variation on solution properties of hydrotropes: phenyl versus cyclohexyl chain tips. Langmuir, 2012, 28, 9332-9340, DOI $10.1021 / \mathrm{la} 301222 \mathrm{~m}$.

46 Klevens, H. B. Critical micelle concentrations as determined by refraction. J. Phys. Chem. 1948, 52, 130-148, DOI 10.1021/j150457a013.

47 Klevens, H. B. Structure and aggregation in dilate solution of surface active agents. $J$. Am. Oil Chem. Soc. 1953, 30, 74-80, DOI 10.1007/BF02635002.

48 Götte, E.; Schwuger, M. J. Überlegungen und experimente zum mechanismus des waschprozesses mit primären alkylsulfaten. Tenside 1969, 6, 131-135.

49 Nardello, V.; Chailloux, N.; Joly, G.; Aubry, J.-M. Preparation, amphiphilic properties and lyotropic phase behaviour of new surfactants based on sodium monoalkyl $\alpha, \omega-$ dicarboxylates. Colloids Surf. Physicochem. Eng. Asp. 2006, 288, 86-95, DOI 10.1016/j.colsurfa.2006.04.026.

50 Laughlin, R. G. The aqueous phase behavior of surfactants, Academic Press London, 1994, vol. 6 . 
51 Boyd, B. J.; Drummond, C. J.; Krodkiewska, I.; Grieser, F. How chain length, headgroup polymerization, and anomeric configuration govern the thermotropic and lyotropic liquid crystalline phase behavior and the air-water interfacial adsorption of glucose-based surfactants. Langmuir 2000, 16, 7359-7367, DOI 10.1021/la991573w.

52 Adasch, V.; Hoffmann, B.; Milius, W.; Platz, G.; Voss, G. Preparation of alkyl $\alpha$ - and $\beta-$ D-glucopyranosides, thermotropic properties and X-ray analysis. Carbohydr. Res. 1998, 314, 177-187, DOI 10.1016/S0008-6215(98)00302-4.

53 Ontiveros, J. F.; Pierlot, C.; Catté, M.; Molinier, V.; Salager, J.-L.; Aubry, J.-M. Structure-interfacial properties relationship and quantification of the amphiphilicity of well-defined ionic and non-ionic surfactants using the PIT-slope method. J. Colloid Interface Sci. 2015, 448, 222-230, DOI 10.1016/j.jcis.2015.02.028.

54Lukowicz, T. Synergistic solubilisation of fragrances in binary surfactant systems and prediction of their EACN value with COSMO-RS. Ph.D. thesis, Université Lille 1, 2015.

55 Cayias, J. L.; Schechter, R. S.; Wade, W. H. Modeling crude oils for low interfacial tension. Soc. Pet. Eng. J. 1976, 16, 351-357, DOI 10.2118/5813-PA.

56 Queste, S.; Salager, J. L.; Strey R.; Aubry, J.-M. The EACN scale for oil classification revisited thanks to fish diagrams. J. Colloid Interface Sci. 2007, 312, 98-107, DOI 10.1016/j.jcis.2006.07.004.

57 Winsor, P. A. Solvent properties of amphiphilic compounds. Butterworths Scientific Publications, London, 1954.

58 Salager, J.-L.; Forgiarini, A. M.; Bullón, J. How to attain ultralow interfacial tension and three-phase behavior with surfactant formulation for enhanced oil recovery: A review. 
Part 1. Optimum formulation for simple surfactant-oil-water ternary systems. $J$. Surfactants Deterg. 2013, 16, 449-472, DOI 10.1007/s11743-013-1470-4.

59 Stubenrauch, C.; Sottmann, T. Sugar-based surfactants: fundamentals and applications. CRC Press, 2008. volume 143.

60 Shinoda, K.; Yamaguchi, T.; Hori, R. The surface tension and the critical micelle concentration in aqueous solution of $\beta$-D-alkyl glucosides and their mixtures. Bull. Chem. Soc. Jpn. 1961, 34, 237-241, DOI 10.1246/bcsj.34.237.

61 Ontiveros, J. F.; Pierlot, C.; Catté, M.; Molinier, V.; Salager, J.-L.; Aubry, J.-M. A simple method to assess the hydrophilic lipophilic balance of food and cosmetic surfactants using the phase inversion temperature of $\mathrm{C}_{10} \mathrm{E}_{4} / n$-octane/water emulsions. Colloids Surf. Physicochem. Eng. Asp. 2014, 458, 32-39, DOI 10.1016/j.colsurfa.2014.02.058.

62 Sagitani, H.; Hayashi, Y.; Ochiai, M. Solution properties of homogeneous polyglycerol dodecyl ether nonionic surfactants. J. Am. Oil Chem. Soc. 1989, 66, 146-152.

63 Rosen, M. J. Surfactants and interfacial phenomena. Wiley-Interscience, Hoboken, New Jersey. 2004.

C-C bond linked 1,2,3,4-tetraol surfactants were prepared from unprotected 1,3dihydroxyacetone (DHA) through aldolisation/reduction. 

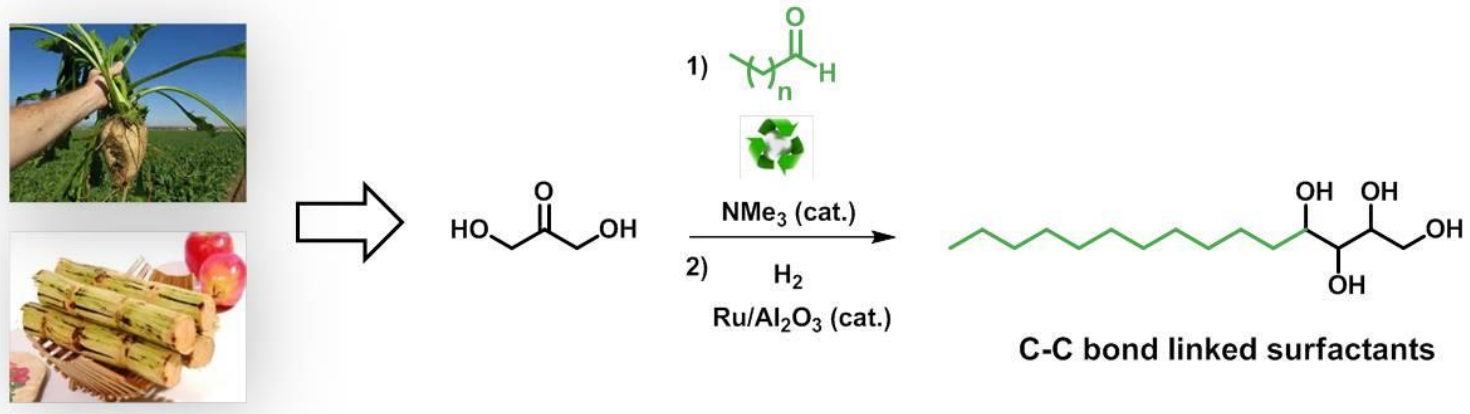

C-C bond linked surfactants 